\title{
ROOT CANAL MORPHOLOGY OF MANDIBULAR PRIMARY MOLARS: A MICRO-CT STUDY
}

\begin{abstract}
Objectives: Frequency of typical and non-typical root and canal morphology of primary teeth, which in clinical practice cannot be detected using 2D radiographic images, should be known by clinicians to decrease failures arising from complexity of root canal morphologies. The aim of this in vitro study was to evaluate morphologic variations in mandibular primary molars' root canal systems.
\end{abstract}

Materials and Methods: Primary mandibular $1^{\text {st }}(n=17)$ and $2^{\text {nd }}(n=33)$ molars were scanned using micro-CT. 3D root models were obtained and root canal morphologies were evaluated according to a modified Vertucci classification. Type 1 and Type 4 canal morphologies were evaluated as 'normal' and all other types and 'non-typical' canal morphology were evaluated as 'abnormal' root canal morphology.

Results: Most common root canal morphology among mandibular primary $1^{\text {st }}$ molars were Vertucci Type 4 morphology for both mesial and distal roots (47\% and $41.2 \%$ respectively), and non-typical morphology for both the mesial and distal roots ( $45.7 \%$ and $21.2 \%$ respectively) of mandibular primary $2^{\text {nd }}$ molars.

Conclusions: Wide range of morphologic variations and frequency of non-typical morphology could be seen especially among mandibular primary $2^{\text {nd }}$ molars and use of disinfectant irrigants and root canal fillings with high antibacterial efficacies are important in order to decrease failures arising from these inaccessible areas.

Key words: Microcomputed tomography, root canal, tooth deciduous.

\author{
Meryem ZIYYA ${ }^{1}$ \\ *Burcu Nihan YÜKSEL ${ }^{1}$ \\ D Şaziye SARI ${ }^{1}$
}

ORCID IDs of the authors:

M.Z. 0000-0003-4756-3348

B.N.Y. 0000-0002-8133-6627

Ş.S. $0000-0003-2202-5148$ ${ }^{1}$ Department of Pediatric Dentistry, Faculty of
Dentistry, Ankara University, Ankara, Turkey

$\begin{array}{ll}\text { Received } & : 05.08 .2019 \\ \text { Accepted } & : 25.09 .2019\end{array}$

How to Cite: Ziya M, Yüksel BN, Sarı Ş. Root Canal Morphology of Mandibular Primary Molars: A Micro-CT Study. Cumhuriyet Dent J 2019;22:4;

*Corresponding Author:

Department of Pediatric Dentistry, Faculty of Dentistry, Ankara University, Ankara, Turkey.

Phone: +90 3122965544 Fax: +90 3122123954 Email: bncelik@ankara.edu.tr 


\section{INTRODUCTION}

It was clearly known that fundamentally the main philosophy of a root canal treatment is filling all the spaces from which pulp removal was done in the root canal following shaping and cleaning procedures. $^{1-3}$ From this point of view, it is necessary to have an idea about all the internal morphological diversity in the root canal system where the pulp is likely to occupy space. ${ }^{1}$

Root canal treatment consists of access cavity preparation and determination of working length, followed by chemo-mechanical preparation and obturation of root canal system in both dentitions. ${ }^{4,5}$ Although root canal treatment applications of primary and permanent teeth are similar primary teeth require a different approach due to both continuous change in the location and size of the apical opening and morphologic variations as an outcome of secondary dentin deposition. ${ }^{5-7}$ Both situations cause a limitation on the chemomechanical preparation and hermetically obturation of the root canals. ${ }^{8}{ }^{8}$ Leaving untreated canals due to a lack of detecting all root canals was reported as the major cause of failures in root canal therapy. ${ }^{89}$ Therefore, a thorough knowledge about root canal morphology and variations in the root canal systems is needed in order to alter any possible complication during each of these stages and improve the success of treatment. ${ }^{10}$

Root canal treatment of primary incisors and canines are performed more easily as they generally exhibit only one root and root canal. ${ }^{5}$ However, in cases where a root exhibits two root canals, especially as in the mesial roots of mandibular primary molars, deposition of secondary dentin in multi-rooted teeth causes small fins, lateral fibrils and connecting branches between canals and formation of a non-typical morphologic structure which cannot be clinically detected $^{5}$, leading to failures in an effective chemomechanical preparation and obturation of the root canals during treatment. ${ }^{11}$

In clinical practice, complexity of the root canal morphology and variations such as lateral canals, apical ramifications or interconnecting branches cannot be detected through the radiographs. ${ }^{12}$ Root canal morphology of primary teeth has been evaluated in vitro with different methods such as; material injection ${ }^{13-16}$, dye perfusion ${ }^{17}$, digital radiographs ${ }^{18}$, longitudinal and transverse crosssectioning ${ }^{18-19}$, clearing technique ${ }^{10,19-21}$, Scanning Electron Microscopy (SEM $)^{22}$, Cone-Beam Computed Tomography (Cone-beam CT) ${ }^{23}$ and micro-CT. ${ }^{9,24}$ Micro-CT, which is recently used in many different fields in dentistry, is a fast, reproducible, non-invasive and non-destructive method, providing more accurate and complete results when compared to other CT methods. ${ }^{25-27} \mathrm{In}$ addition, the resolution of voxels ranging from 1-50 $\mu \mathrm{m}$ ensures that even very small and complex objects can be displayed. Micro-CT has been proven to be a very effective method in imaging and studying the complex structure of root canal morphology. ${ }^{28,29}$

Most of the morphologic studies in primary teeth, in which root canal morphology was defined according to number of only the main root canals and connecting branches, lateral fibrils were evaluated separately, seem to lack in defining morphologic variations in a systematic classification as in permanent teeth. Despite all the studies systematically trying to define the diversity of canal configurations, it is seen that there may still be too many atypical canal systems and there is still no classification system suitable for all tooth types. ${ }^{30}$ Considering the limitations of evaluation methods used in studies and limited number of studies carried out using a systematic classification, a detailed description of the variations in root canal morphology of primary teeth is still lacking in the literature. Therefore, the present study aimed to evaluate the morphological variations seen in the root canal systems of the mandibular primary molars within a systematic classification by using micro-CT.

\section{MATERIALS AND METHODS}

The study protocol was approved by the research ethics committee of Ankara University Faculty of Dentistry (36290600/23-2015).

\section{Sample Selection}

Mandibular primary molars extracted for several reasons were selected from among patients attending pediatric clinic. According to the Power Analysis; to obtain results with maximum $20 \%$ 
error, with 5\% Type 1 error and $80 \%$ power level, at least 49 teeth were required.

Total of 50 mandibular primary molars [first molars $(n=17)$ and second molars $(n=33)]$ were selected according to the inclusion criteria which was determined as teeth could be included in the study when the apical root resorption level did not exceed $1 / 3$ of total root length. Soft tissues and debris on the surface of the extracted teeth were removed and cleaned with a toothbrush and scaler under tap water. Specimens were stored in a $0.2 \%$ thymol solution until used.

\section{Micro-CT Scanning and Reconstruction}

Each tooth was slightly dried and mounted on a wax block and scanned in a micro-CT scanner (Bruker Micro-CT 1172, Kontich, Belgium) at a pixel resolution of $12.5 \mu \mathrm{m}$. The X-ray tube was operated at $100 \mathrm{kV}$ and $100 \mathrm{~mA}$, and the scanning was performed by $360^{\circ}$ rotation around the vertical axis with a rotation step of $0.4^{\circ}$, using a $0.5-\mathrm{mm}$ thick aluminum filter. Each image was composed from the average of three poses obtained from each tooth. Duration for each pose is $1750 \mathrm{~ms}$. Depending on the size of the specimen, an average of 1400 cross section was obtained. Images of each specimen were reconstructed with Nrecon software (Nrecon v. 1.7.1.0, Bruker_microCT) providing axial cross sections of the inner structure of the samples.

\section{Qualitative Analysis}

Data analysis and reconstructions of threedimensional models were done based on CTAn software (CTAn, v.1.13, Bruker_microCT), imaging was done using CTVox software (CTVox,
Bruker_microCT) and solid state of models were imaged on CTVol software (CTVol, Bruker_microCT). Using CTAn software (CTAn, v.1.13, Bruker_microCT), choosing certain intervals on gray scale (0-255), separate models of root canal space and tooth structure were obtained. These models were then combined together using CTVol software (CTVol, Bruker_microCT). For a more accurate morphologic evaluation, models of mesial and distal roots of each tooth were obtained separately. Color settings were selected to show the root canal space (pink-red) in the 3D images of the tooth structures.

\section{Morphologic Classification}

Using models obtained via micro-CT, root canal morphologies of mesial and distal roots of mandibular primary first and second molars were determined according to Vertucci Classification. ${ }^{4}$ Root canal morphologies non-classifiable with Vertucci's Classification, were recorded as nontypical root canal morphology that was earlier defined by Sar1 and Aras. ${ }^{20}$ According to this, single canal in a root (Vertucci Type 1) and two separate canals in a root (Vertucci Type 4) were evaluated as 'normal' canal morphology, while all other Vertucci canal types and non-typical root canal structures were all together categorized as 'abnormal' canal morphology. Frequency distribution of root canal morphology types of mandibular primary molars' mesial and distal roots were shown with numbers and percentages.

\section{RESULTS}

Data obtained from the evaluation of root canal morphology according to modified Vertucci Classification are given in Table 1. 
Table 1. Root Canal Morphology of Mandibular Primary Molars ( $n=50)$

\begin{tabular}{|c|c|c|c|c|c|c|c|c|c|c|c|c|c|}
\hline \multicolumn{14}{|c|}{ Canal Types } \\
\hline Tooth & Root & $\begin{array}{c}\text { Root } \\
\text { Number }\end{array}$ & $\begin{array}{c}\text { Type } \\
1\end{array}$ & $\begin{array}{c}\text { Type } \\
2\end{array}$ & $\begin{array}{c}\text { Type } \\
3\end{array}$ & $\begin{array}{c}\text { Type } \\
4\end{array}$ & $\begin{array}{c}\text { Type } \\
5\end{array}$ & $\begin{array}{c}\text { Type } \\
6\end{array}$ & $\begin{array}{c}\text { Type } \\
7\end{array}$ & $\begin{array}{c}\text { Type } \\
8\end{array}$ & $\begin{array}{l}\text { Non- } \\
\text { Typical }\end{array}$ & $\begin{array}{c}\text { Normal } \\
\text { Canal } \\
\text { Morphology } \\
\text { (Type } 1 \& \\
\text { Type 4) }\end{array}$ & $\begin{array}{l}\text { Abnormal } \\
\text { Canal } \\
\text { Morphology } \\
\text { (Other canal } \\
\quad \text { types) }\end{array}$ \\
\hline \multirow{2}{*}{$\begin{array}{c}\text { Primary } \\
\text { First } \\
\text { Molar }\end{array}$} & Mesial & 17 & - & - & - & $\begin{array}{c}8 \\
(\% 47)\end{array}$ & $\begin{array}{c}1 \\
(\% 5.9)\end{array}$ & $\begin{array}{c}2 \\
(\% 11.8)\end{array}$ & - & $\begin{array}{c}1 \\
(\% 5.9)\end{array}$ & $\begin{array}{c}5 \\
(\% 29.4)\end{array}$ & $\begin{array}{c}8 \\
(\% 47)\end{array}$ & $\begin{array}{c}9 \\
(\% 53)\end{array}$ \\
\hline & Distal & 17 & $\begin{array}{c}3 \\
(\% 17.6)\end{array}$ & - & $\begin{array}{c}2 \\
(\% 11.8)\end{array}$ & $\begin{array}{c}7 \\
(\% 41.2)\end{array}$ & $\begin{array}{c}3 \\
(\% 17.6)\end{array}$ & - & - & $\begin{array}{c}2 \\
(\% 11.8)\end{array}$ & - & $\begin{array}{c}10 \\
(\% 58.8)\end{array}$ & $\begin{array}{c}7 \\
(\% 41.2)\end{array}$ \\
\hline \multirow{2}{*}{$\begin{array}{l}\text { Primary } \\
\text { Second } \\
\text { Molar }\end{array}$} & Mesial & $35^{*}$ & $\begin{array}{c}4 \\
(\% 11.4)\end{array}$ & $\begin{array}{c}1 \\
(\% 2.9)\end{array}$ & - & $\begin{array}{c}10 \\
(\% 28.6)\end{array}$ & $\begin{array}{c}2 \\
(\% 5.7)\end{array}$ & - & - & $\begin{array}{c}2 \\
(\% 5.7)\end{array}$ & $\begin{array}{c}16 \\
(\% 45.7)\end{array}$ & $\begin{array}{c}14 \\
(\% 40)\end{array}$ & $\begin{array}{c}21 \\
(\% 60)\end{array}$ \\
\hline & Distal & 33 & $\begin{array}{c}2 \\
(\% 6.1)\end{array}$ & $\begin{array}{c}3 \\
(\% 9.1)\end{array}$ & $\begin{array}{c}1 \\
(\% 3)\end{array}$ & $\begin{array}{c}5 \\
(\% 15.1)\end{array}$ & $\begin{array}{c}6 \\
(\% 18.2)\end{array}$ & $\begin{array}{c}2 \\
(\% 6.1)\end{array}$ & $\begin{array}{c}1 \\
(\% 3)\end{array}$ & $\begin{array}{c}6 \\
(\% 18.2)\end{array}$ & $\begin{array}{c}7 \\
(\% 21.2)\end{array}$ & $\begin{array}{c}7 \\
(\% 21.2)\end{array}$ & $\begin{array}{c}26 \\
(\% 78.8)\end{array}$ \\
\hline
\end{tabular}

* 2 out of 33 second primary molars have two mesial roots and one distal root each.

Images of 3D modelled roots and root canals used in determining root canal morphology are shown in Figure 1.

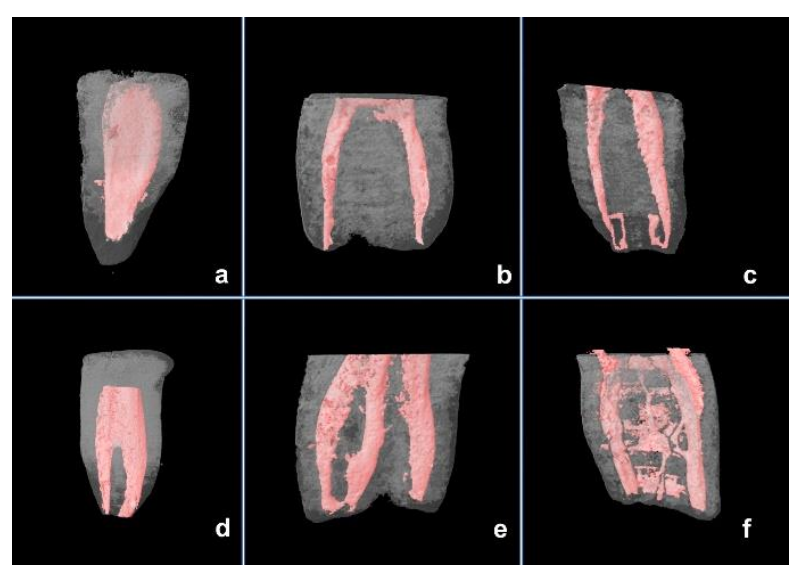

Figure 1. Images obtained from the $3 \mathrm{D}$ models a) Distal root of mandibular primary $1^{\text {st }}$ molar (Vertucci Type 1). b) Distal root of mandibular primary $1^{\text {st }}$ molar (Vertucci Type 4). c) Mesial root of mandibular primary $1^{\text {st }}$ molar (Non-typical). d) Mesial root of mandibular primary $1^{\text {st }}$ molar (Vertucci Type 5). e) Distal root of mandibular primary $2^{\text {nd }}$ molar (Vertucci Type 8). f) Mesial root of mandibular primary $2^{\text {nd }}$ molar (Non-typical)

In Table 1, the frequency distribution of root canal types for mesial and distal roots of mandibular primary first and second molars are given in numbers and percentages. The frequency of 'normal' and 'abnormal' canal morphologies are also given in Table 1.

Three roots were observed in 2 out of 33 mandibular primary second molars [one distal and two separate mesial roots (mesiobuccal and mesiolingual), while all other primary molars $(n=48)$ had two roots.

Vertucci Type $4 \quad(47 \%$ and $41.2 \%$ respectively) was the most common root canal morphology for both mesial and distal roots of mandibular primary first molars while it was the non-typical morphology for primary second molars for both roots [mesial (45.7\%), distal (21.2\%)]. Frequency of 'Abnormal' canal morphologies were enrolled $53 \%$ and $41.2 \%$ in mesial and distal roots of first molars respectively, and $60 \%$ and $78.8 \%$ in mesial and distal roots of second molars.

\section{DISCUSSION}

Although detailed descriptions of root canal morphology of primary molars have been already reported $^{5,14,15,18,19}$, most of these studies seem to lack in defining morphologic variations in a systematic classification in which only the prevalence of one or two root canals were reported and connecting branches, lateral fibrils were evaluated separately. So, the present study has aimed to analyze the detailed images of the root canal morphology and determine the frequency of complex morphologies of primary molars. Vertucci's Classification ${ }^{4}$ which form the basis of the classification systems used in permanent teeth, has identified a total of eight configurations that were more complex than described in earlier studies. ${ }^{30}$ The classification system has been modified by Sar1 and $\operatorname{Aras}^{20}$ in order to define the non-typical root canal variations in primary teeth.

Although new suggestions have come up to define the diversity of canal systems, ${ }^{30}$ the recommendations generally focus on permanent teeth. A more recent study ${ }^{31}$ describes new root and canal classification system for the primary dentition in a similar way as in permanent dentition $^{30}$, however it is reported that the presence 
of physiological root resorption and the presence of permanent sucessors close to the roots of primary teeth may be a challenge to implement this system. In addition, the numbering procedure appears to be somewhat complex and requires clinical experience. For this reasons, it is considered appropriate to use the modified type ${ }^{20}$ of Vertucci system used in primary teeth in this present study.

Primary incisors and canines have been reported to have less complex root canal morphologies compared to primary molars. ${ }^{19,32}$ Root canal number of both mandibular and maxillary molars vary between 2-5,10,20,32,34, resulting with greater morphologic variations in their root canal systems, which has been reported to be most frequent especially in mandibular primary molars. ${ }^{13,20,34}$ Regarding this, the present study was carried out on mandibular primary first and second molars.

The present study has shown that $47.1 \%$ of mesial roots of mandibular primary first molars have Vertucci Type 4 canal morphology. This result takes part in the range $24-100 \%$, which was reported in previous studies. ${ }^{8-10,13,20,23,24,33}$ Vertucci Type 4 was the most common also in distal roots of mandibular primary first molars $(41.2 \%)$. The only study that we can compare the findings of the canal morphology we have obtained from the present study within the systematic classification is a study using clearing technique, carried out by Sarı and Aras, ${ }^{20}$ in which Vertucci Type 1 was the most common root canal morphology reported for distal roots of first molars (70\%), while only $9.3 \%$ of them had Type 4 morphology. The difference between the research findings is thought to be caused by the difference in the methods used in the study. Hence, the clearing technique used in that study has some limitations; due to weakened tooth structures during demineralization process, the weakened tooth could be bent during the handling process of the specimen, causing small structures like accessory canals or isthmuses to be affected even by a slight distortion. This morphological distortion could result in closure or narrowing of accessory canals. ${ }^{35}$ It is more appropriate to compare our findings with the results of micro-CT studies $^{9,24}$ carried out with limited number of samples, which have reported $50-60 \%$ of two root canals in distal roots of mandibular primary first molars.

In this present study, the most common canal morphology determined in both mesial and distal roots of mandibular primary second molars was non-typical morphologic structure $(45.7 \%$ and $21.2 \%$ respectively). In the single study, in which canal types non-classifiable with Vertucci's classification were considered as non-typical canal morphology, it has been emphasized the prevalence of non-typical canal morphology in both mesial and distal roots to be $(28 \%$ and $8 \%$ respectively). ${ }^{20}$ Additionally, Vertucci Type 4 was the most common (48.6\%) canal morphology among mesial roots of mandibular primary second molars reported also by the single reference study. ${ }^{20}$ In other studies where only canal numbers were reported without systematic classification, the frequency of the occurrence for two canals in mesial roots of second molars was given between $32 \%$ and $100 \% .^{8-10,13,23,24,33}$ In the literature variations like apical ramifications, interconnecting branches and lateral fibrils in the mesial roots of mandibular molars were frequently reported. ${ }^{9,13}$ According to findings reported by a study $^{13}$, canal morphology characterized with these variations was the most frequent $(36 \%)$ in mesial roots of mandibular primary second molars. ${ }^{8}$ Other studies evaluating only the main root canal(s) and not considering variations between the main root canals in determining canal morphology, have reported a higher prevalence of two root canals (85.7\%-100 \%) compared to our findings. ${ }^{8-}$ $10,20,23,24,33$

In this present study, non-typical canal morphology was found to be the most frequent (21.2\%) in the distal roots of the second molars. Type 1 canal morphology was the most common for distal roots reported by Sar1 and Aras ${ }^{20}$, which is followed by Type 4 morphology with $18 \%$ and non-typical morphologic structure with $8 \%$. In the present study, findings for Type 1 canal morphology were much less compared to results reported by Sar1 and $\operatorname{Aras}^{20}$, while similar results for type 4 canal morphology (15.1\%) was obtained. The difference between the results is thought to be 
due to the number of samples used in the study or the methods used to determine the morphology. Prevalence of one root canal and two root canals in distal root of mandibular primary second molars varied between 21-88.9\% and 11.4-100\% respectively among studies. . $^{8,23,24,29-33}$ Morphologic variations that was reported among distal roots of mandibular primary second molars ${ }^{8-}$ ${ }^{10}$ have suggested that on contrary to only one or two root canals reported among studies, nontypical root canal morphology may also be as prevalent, however, prevalence of this morphologic structure may vary among investigation methods. Additionally, perhaps due to the fact that the evaluations were not made in a systematic classification, the canals which can be considered as non-typical according to the modified Vertucci classification, ${ }^{20}$ are determined as one or two canals. For this reason, it is possible to say that the modified classification used in the present study has given a more specific information about canal morphology.

Prevalence of 'normal' canal morphology defining Vertucci Type 1 and Type 4, and 'abnormal' canal morphology, defining all other canal types and non-typical morphological structure, were nearly equal in mesial and distal roots of first molars and mesial roots of second molars ('Normal' canal morphology; 47\%, 58.8\% and $40 \%$ respectively and 'Abnormal' canal morphology; $53 \%, 41.2 \%$ and $60 \%$ respectively). The difference in the frequency was more significant only in distal roots of second molar teeth ('Normal' canal morphology $21.2 \%$ and 'Abnormal' canal morphology 78.8\%). This may be due to wide range of morphologic variations arising from random secondary dentin deposition in the wide, ribbon-like distal roots of second molars.

As a general assessment of 'abnormal canal morphology' recorded in the present study, morphological changes were most likely to appear as ramifications in the apical region. Thus, studies have reported that, in the apical region, continual secondary dentin deposition may develop small fins and connecting branches between canals and divide them into two or more canals. , $^{93,15,20}$

\section{CONCLUSIONS}

Wide range of morphologic variations and frequency of non-typical morphology especially among mandibular primary 2nd molars, which in clinical practice cannot be detected using 2D radiographic images, should be considered during root canal treatment. Depending on these results, it is suggested that, during root canal treatment, use of disinfectant irrigants and root canal fillings with antibacterial efficacies are important in order to decrease failures arising from these inaccessible areas. Further studies are essential to create a general classification system including all diversities for the root canal system in primary teeth and more research are needed to evaluate the effect of variations among primary teeth root canal morphology on success of root canal filling.

\section{ACKNOWLEDGEMENTS}

None

\section{CONFLICT OF INTEREST STATEMENT}

The authors deny any conflicts of interest related to this study.

\section{Alt Süt Azı Dişslerinin Kanal Morfolojileri: Bir Mikro- BT Çalışması}

$\ddot{O} Z$

Amaç: Süt dişlerinin kök kanal sistemlerinde sik rastlanan ancak klinik pratiğinde $2 D$ radyografiler üzerinden tespit edilmesi mümkün olmayan morfolojik varyasyonlar, morfolojiden kaynaklanan başarisızlğın en aza indirgenebilmesi için klinik uygulamalarda hekim tarafindan dikkate alinmalıdir. In-vitro olarak gerçekleştirilen bu çalışmada, alt süt azı dişlerin kök kanal morfolojilerindeki varyasyonların çeșittiliğinin değerlendirilmesi amaçlanmıştır. Gereç ve Yöntemler: 50 adet alt süt azl diş, [süt 1. azl ( $n=17)$, süt 2. azl $(n=33)$ ] yüksek çözünürlüklü mikro-BT ile taranmıştır. Mikro-BT ile örneklerin $3 D$ görüntü ve modellerinin elde edilmesini takiben Vertucci sinfflamasina atipik kanal morfolojisi de ilave edilerek kanallardaki morfolojik varyasyonlar gruplandirlmuştrr. Tip 1 ve Tip 4 kanal tipi 'normal' morfololoji, bunun dişında kalan tüm kanal tipleri ise 'anormal' morfoloji olarak değerlendirilmiştir. Elde edilen veriler sayl ve yüzde (\%) ile gösterilmişstir. Bulgular: Alt süt 1. azı dişi için, mesial ve distal kökte en sik Tip 4 morfoloji (strasıyla \%47 ve \%41,2); süt 2. azı dişi için ise, mesial ve distal kökte en sık atipik morfolojikyapı (slrastyla 
$\% 45,7$ ve \%21,2) tespit edilmiştir. Sonuçlar: Atipik morfolojik varyasyonların süt azı dişlerinde çok geniş bir aralıkta ve sıklıkta görüldüğü ve özellikle alt çene süt ikinci azı dişlerinde gözlendiği dikkate alınarak, bu dişlerle ilgili planlanan endodontik tedaviler sirasında ulaşılamayan alanlardan kaynaklanan başarısızliğın en aza indirgenebilmesi için antibakteriyel etkinliğe sahip olan kanal dezenfektanı ve kanal dolgu materyali kullanımının önemli olduğu sonucuna varllmıştır. Anahtar kelimeler: Taurodontizm, Mikrobilgisayarl Tomografi, Süt dişi, Kalıcı diş.

\section{REFERENCES}

1. Kurthukoti AJ, Sharma P, Swamy DF, Shashidara R, Swamy EB. Computed tomographic morphometry of the internal anatomy of mandibular second primary molars. Int J Clin Pediatr Dent 2015;8:202-207.

2. Arslan I, Aydinoglu S, Baygin O, Tuzuner T, Sirin M. Comparative Analysis of Manual, Rotary and Reciprocal Systems on Primary Teeth Root Canals: An In Vitro Scanning Electron Microscopy Study. Cumhuriyet Dent J 2019;22:299-309.

3. Güler Ç, Gurbuz T, Yilmaz Y. The clinical success of different root canal treatments in primary molars. Cumhuriyet Dent J 2013;16:31-39.

4. Vertucci FJ. Root canal anatomy of the human permanent teeth. Oral Surg Oral Med Oral Pathol 1984;58:589-599.

5. Goerig AC, Camp JH. Root canal treatment in primary teeth: A review. Pediatr Dent 1983;5:33-37.

6. Rimondini L, Baroni C. Morphologic criteria for root canal treatment of primary molars undergoing resorption. Endod Dent Traumatol 1995;11:136-141.

7. Camp JH, Fuks AB. Pediatric endodontics: endodontic treatment for the primary and young permanent dentition. In: Cohen S, Hargreaves KM, eds. Pathways of the pulp. 9th ed. St Louis: Mosby, 2006:822-882.

8. Sarkar S, Rao AP. Number of root canals, their shape, configuration, accessory root canals in radicular pulp morphology. A preliminary study. J Indian Soc Prev Dent 2002;20:93-97.

9. Fumes AC, Sousa-Neto MD, Leoni GB, Versiani MA, Da Silva RAB, Consolaro A. Root canal morphology of primary molars: a micro-computed tomography study. Eur Arch Paediatr Dent 2014;15:317-326.

10. Bagherian A, Kalhori KAM, Sadeghi M, Mirhosseini F, Parisay I. An in vitro study of root and canal morphology of human deciduous molars in an Iranian population. J Oral Sci 2010;52:397-403.

11. Moskovitz M, Tickotsky N. Pulpectomy and Root Canal Treatment (RCT) in Primary Teeth: Techniques and Materials. In: Fuks AB, Peretz B, eds. Pediatric Endodontics: Current Concepts in Pulp Therapy for Primary and Young Permanent Teeth. 1st ed. Switzerland: Springer International Publishing, 2016:71-101.

12. Nattress BR, Martin DM. Predictability of radiographic diagnosis of variations in root canal anatomy in mandibular incisor and premolar teeth. Int Endod J 1991;24:58-62.

13. Hibbard ED, Ireland RL. Morphology of the root canals of the primary molar teeth. ASDC J Dent Child 1957;24:250-257.

14. Rosentiel E. Transparent model teeth with pulps. Dent Dig 1957;3:154-157.

15. Simpson WJ. An examination of root canal anatomy of primary teeth. J Can Dent Assoc 1973;39:637-640.

16. Barker BCW, Parsons KC, Williams GL, Mills PR. Anatomy of root canals. IV deciduous teeth. Aust Dent J 1975;20:101-106.

17. Ringelstein D, Seow WK.The prevalence of furcation foramina in primary molars. Pediatr Dent 1989;11:198-202.

18. Poornima P, Subba Reddy VV. Comparison of digital radiography, decalcification, and histologic sectioning in the detection of accessory canals in furcation areas of human primary molars. J Indian Soc Pedod Prev Dent 2008;26:49-52.

19. Salama FS, Anderson RW, McKnight-Hanes C, Barenie JT, Myers DR. Anatomy of primary incisor and molar root canals. Pediatr Dent 1992;14:117-118.

20. Sarı Ş, Aras Ş. Süt molar dişlerin kök- kanal morfolojisi. AU Diş Hek Fak Derg 2004;31:157-167.

21. Gupta D, Grewal N. Root canal configuration of deciduous mandibular first molars-An in vitro study. J Indian Soc Pedod Prev Dent 2005;23:134-137.

22. Wrabas KT, Kielbassa AM, Hellwig E. Microscopic studies of accessory canals in primary molar furcations. ASDC J Dent Child 1997;64:118-122.

23. Ozcan G, Sekerci AE, Cantekin K, Aydınbelge M, Dogan S. Evaluation of root canal morphology of human primary molars by using CBCT and comprehensive review of the literature. Acta Odontol Scand 2016;74:250-258. 
24. Wang YL, Chang HH, Kuo CI, Chen SK, Guo MK, Huang GF, Lin CP. A study on the root canal morphology of primary molars by high-resolution computed tomography. J Dent Sci 2013;8:321-327.

25. Hammad M, Qualtrough A, Silikas N. Evaluation of root canal obturation: a three-dimensional in vitro study. J Endod 2009;35:541-544.

26. Jung M, Lommel D, Klimek J. The imaging of root canal obturation using micro-CT. Int Endod $\mathrm{J}$ 2005;38:617-626.

27.Zogheib C, Naaman A, Sigurdsson A, Medioni E, Bourbouze G, Arbab Chirani R. Comparative microcomputed tomographic evaluation of two carrier-based obturation systems. Clin Oral Invest 2013;17:18791883.

28. Villas-Boas $\mathrm{MH}$, Bernardineli $\mathrm{N}$, Cavenago BC, Marciano M, Del Carpio-Perochena A, De Moraes IG, Duarte MH, Bramante CM, Ordinola-Zapata R. Microcomputed tomography study of the internal anatomy of mesial root canals of mandibular molars. J Endod 2011;37:1682-1686.

29. Versiani MA, Pecora JD, De Sousa-Neto MD. Root and root canal morphology of four-rooted maxillary second molars: a micro-computed tomography study. J Endod 2012;38:977-982.
30. Ahmed HMA, Versiani MA, De-Deus G, Dummer $\mathrm{PMH}$. A new system for classifying root and root canal morphology. Int Endod J 2017;50:761-770.

31. Ahmed HMA, Musale P, Alshahawy OI, Dummer $\mathrm{PMH}$. Application of a new system for classifying tooth, root and canal morphology in the primary dentition. Int Endod J 2019; doi: 10.1111/iej.13199. [Epub ahead of print]

32. Gaurav V, Srivastana N, Rana V, Adlakha VK. A study of root canal morphology of human primary incisors and molars using cone beam computerized tomography: An in vitro study. J Indian Soc Pedod Prev Dent 2013;31:254-259.

33. Aminabadi NA, Farahani RM, Gajan EB. Study of root canal accessibility in human primary molars. J Oral Sci 2008;50:69-74.

34. Yang R, Yang C, Liu Y, Hu Y, Zou J. Evaluate root and canal morphology of primary mandibular second molars in Chinese individuals by using cone-beam computed tomography. J Formosan Med Assosciation 2013;112:390-395.

35. Chang SW, Lee JK, Lee Y, Kum KY. In-depth morphological study of mesiobuccal root canal systems in maxillary first molars: review. Restor Dent Endod 2013;38:2-10. 